\title{
Water Budget formulation for Ahmadu Bello University, main Campus as a Water Resources Management Option
}

\section{*1ADAMA, BABA; KRZYSZTOF, SCHOENEICH; ENOCH, A. IKPOKONTE}

\author{
Department of Geology and Mining, Faculty of Natural and Applied Science, Nasarawa State University, Keffi, \\ Corresponding author.adamababa2000@yahoo.com \\ Department of Geology, Ahmadu Bello University, Zaria.Email:schoeneich2003@yahoo.com,awa_ikpo@yahoo.com
}

\begin{abstract}
This study provides a water resources management option through formulation of water budget for the main campus of the Ahmadu Bello University, Zaria using secondary data obtained from various sources. The data revealed that, water consumption in the campus in the year 2005 was $3,101 \mathrm{~m}^{3} / \mathrm{d}$ and $3,125 \mathrm{~m}^{3} / \mathrm{d}$ in year 2015 . Available total surface water resources (ATSWR) are $24,410 \mathrm{~m} 3 / \mathrm{d}$ while utilizable total surface water resources (UTSWR) are $3,214 \mathrm{~m}^{3} / \mathrm{d}$. The investigation shows that, at the time of this study ATSWR was more than UTSWR. The Authors prepare water budget: Total surface water resources (TSWR) in the campus are $24,410 \mathrm{~m}^{3} / \mathrm{d}$ while utilizable surface water resources (USWR) are $3,214 \mathrm{~m}^{3} / \mathrm{d}$. @JASEM

http://dx.doi.org/10.4314/jasem.v20i2.27
\end{abstract}

KEYWORDS: Water Resources, Supply, Consumption, Demand, Utilizable, Upper, Middle, and Lower fine/coarse Member, Older Alluvial aquifer

\section{Introduction}

The surface water supply scheme to the main campus of the Ahmadu Bello University, Samaru, Zaria, is getting dilapidated. The irregular water flow has been attributed to silting up of the Kubanni Dam and increase water demand in the campus which has grown beyond installed capacity of the waterworks. As a remedy, Ahmadu Bello University embarked on drilling boreholes to supplement its depleting surface water scheme. The boreholes started drying up after few months of drilling. With low voltage to turn the pumps, it is believed that the waterworks pumps are old, worn out, low yield and dropped pumping head. The distribution pipe work is old, corroded and incrustated. With increase in the population of water consumers in the campus, the ABU water supply scheme which was constructed over thirty years ago can meet its water demand because the installed capacity of the scheme exceeds its present water demand. Due to unavailability of data, the size of the population, how much quantity of water the campus consume, yield and pumping head of the pumps is not known. The authors observed that all may be true but there is no data on which the evidence can be ascertain. To improve the prospects of regular water supply to the campus the basic reasons and facts on the amount of water available (both surface and ground) should form the water budget. According to Garba (2000) the configuration of $\mathrm{ABU}$ dry season water table shows that all its surface water drain to the reservoir. Therefore, the purpose of this research is to produce water budget for the campus. Without which there will be irregular water supply in the campus. The water consumption in 2005 is shown in Table 1 below.

\begin{tabular}{lccc}
\hline Table 1. Water consumption at the Ahmadu Bello University main Campus in Year 2005 \\
\hline Category of water & population Unit water & Water Consumers size \\
& consumption, & Ipcd & consumption $\mathrm{m}^{3} / \mathrm{d}$ \\
Resident staff with dependents & 10,570 & 100 & 1,057 \\
Students in the hostels & 15,242 & 100 & 1,524 \\
Day time staff o pensionable appointment & 5,316 & 10 & 53 \\
Day time tertiary students & 2,065 & 10 & 21 \\
Day time primary and secondary students & 3,273 & 10 & 33 \\
Daily paid workers & 850 & 10 & 9 \\
Teaching area, various uses lump-sum & - & & 50 \\
Gardening, teaching area, 8,000 $\mathrm{m}^{2}, 1 \mathrm{~m}^{3} / \mathrm{m}^{2} / \mathrm{a}$ & - & $2.71 / \mathrm{m}^{2} / \mathrm{d}$ & 22 \\
Gardening, residential area, lump-sum & & & 50 \\
Subtotal & & & 2,819 \\
Spillages and wastages, $10 \%$ of the subtotal & & 282 \\
Total water consumption in the year 2005 & & 3,101 \\
Total water consumption in the year 2015 & & 3,125 \\
\hline
\end{tabular}


The geological map shows the topography of the area and the Kubanni River with its tributaries (Figure 1) discharging into the Kubanni Reservoir. The Impounding Reservoir is one of the available surface water reservoir in the campus and have a total storage of 2,600,000 $\mathrm{m}^{3}$, open water table is $60 \mathrm{ha}$, and drainage basin $54 \mathrm{~km}^{2}$ (CWRS, 2004). Dan Fodio
(Samaru) is the only perennial stream in the Kubanni River drainage basin. It is mostly fed by the groundwater discharge from Samaru. Agema (2007), estimated the Samaru groundwater discharge as two litres per second in the wet season and 0.5 litres in the dry season, annual average $11 / \mathrm{s}$ or $31,536 \mathrm{~m}^{3} / \mathrm{a}$

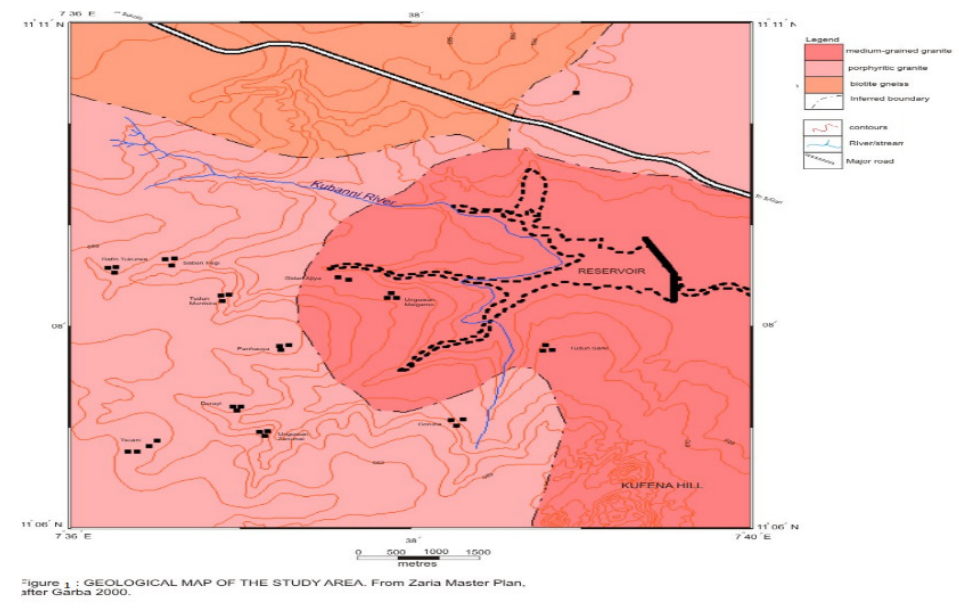

\section{MATERIALS AND METHODS}

The methods of study involves desk study and field work. The mapping was done with the aid of field equipment such as geological hammer, compass, measuring tape, Global Positioning System (GPS), masking tape and writing materials. The fieldwork spanned for a years, during which the authors collected sample and data from drilling of boreholes and sinking of hand-dug well. Grids of geographical coordinates were introduced on the base map. During the field work the borehole logs were plotted and their points of measurement were located using Garmin satellite navigator, its horizontal accuracy 10 meters. Results of depth measurements are shown in Table 2 and 3. Map of location and names of water wells /boreholes in the study area were produced as shown in Fig 2.

\section{RESULTS AND DISCUSSION}

See table 2 and 3 for the results of the boreholes/well drilled and their locations in the study area. It is noteworthy that in all boreholes drilled under alluvial sands, fresh rock underlay the alluvial sands. Most likely saprolite where removed by the river which deposited the sands. Fresh crystalline rock could not be petrologically identified, because the rocks were powered by the down-the-hole hammer. It is either granite or any metamorphic rock described as 'migmatite gneiss'. The boreholes were drilled by National Water Resources Institute (2002). The crystalline rock has been identified as granite

Table 2. Some Results of The Water Wells Drilled and sunk in the Abu Teaching Area to supplement Surface Water Supply. Groundwater elevation of all wells was read from the base map and converted to meters. Conversion factor from meters to feet is 0.304805 .

\begin{tabular}{|c|c|c|c|c|c|c|c|}
\hline Water well & Completion date & $\begin{array}{l}\text { Ground level } \\
\text { elevation } \\
\mathrm{m} \text { asl feet asl }\end{array}$ & $\begin{array}{l}\text { Depth to } \\
\text { water table m } \\
\text { bgl, } \\
\text { feet bgl }\end{array}$ & $\begin{array}{l}\text { Elevation of } \\
\text { water table } \\
\mathrm{m} \text { asl feet asl }\end{array}$ & $\begin{array}{l}\text { Yield of } \\
\text { the well 1/s }\end{array}$ & $\begin{array}{l}\text { Depth to } \\
\text { crystalline rock, } \\
\text { m bgl, feet bgl }\end{array}$ & $\begin{array}{l}\text { Crystall. } \\
\text { Rock } \\
\text { Elevation } \\
\text { m asl feet asl }\end{array}$ \\
\hline \multirow[t]{2}{*}{ Amina 1} & 30.04 .05 & $670.8 \mathrm{~m}$ & $4.5 \mathrm{~m}$ & $666.3 \mathrm{~m}$ & 1.3 & $25.0 \mathrm{~m}$ & $645.9 \mathrm{~m}$ \\
\hline & & 2201.0' & $14.8^{\prime}$ & 2186.2' & & $82.0^{\prime}$ & $2119.0^{\prime}$ \\
\hline \multirow[t]{2}{*}{ Amina 2} & 1.05 .05 & $670.8 \mathrm{~m}$ & $4.0 \mathrm{~m}$ & $666.8 \mathrm{~m}$ & 1.2 & $23.0 \mathrm{~m}$ & $647.9 \mathrm{~m}$ \\
\hline & & 2201.0' & $13.1^{\prime}$ & 2187.9' & & $75.5^{\prime}$ & 2125.5 \\
\hline \multirow[t]{2}{*}{ Ribadu 1} & 15.04 .05 & $669.4 \mathrm{~m}$ & $4.5 \mathrm{~m}$ & $664.9 \mathrm{~m}$ & 1.2 & $25.0 \mathrm{~m}$ & $644.4 \mathrm{~m}$ \\
\hline & & 2196.0 ' & $14.8^{\prime}$ & 2181.2' & & $82.0^{\prime}$ & 2114.0' \\
\hline \multirow[t]{2}{*}{ Ribadu 2} & 19.04 .05 & $669.7 \mathrm{~m}$ & $3.4 \mathrm{~m}$ & $666.0 \mathrm{~m}$ & 1.3 & $20.0 \mathrm{~m}$ & $649.4 \mathrm{~m}$ \\
\hline & & $2187.5^{\prime}$ & 11.2' & 2184.8 & & $65.6^{\prime}$ & 2130.4 \\
\hline \multirow[t]{2}{*}{ Library } & 10.10 .05 & $666.7 \mathrm{~m}$ & $4.5 \mathrm{~m}$ & $662.2 \mathrm{~m}$ & 1.5 & $20.0 \mathrm{~m}$ & $646.8 \mathrm{~m}$ \\
\hline & & 2187.5 & $14.8^{\prime}$ & 2172.7 & & $65.6^{\prime}$ & 2121.9' \\
\hline
\end{tabular}




\begin{tabular}{|c|c|c|c|c|c|c|c|}
\hline \multirow[t]{2}{*}{ Akenzua 1} & 4.06 .05 & $665.9 \mathrm{~m}$ & $4.0 \mathrm{~m}$ & $663.5 \mathrm{~m}$ & 0.6 & $18.0 \mathrm{~m}$ & $650.1 \mathrm{~m}$ \\
\hline & & 2192.0' & $13.1^{\prime}$ & 2178.9' & & 59.1 ' & 2132.9' \\
\hline \multirow[t]{2}{*}{ Akenzua 2} & 7.06 .05 & $667.5 \mathrm{~m}$ & $4.5 \mathrm{~m}$ & $663.0 \mathrm{~m}$ & 0.4 & $22.0 \mathrm{~m}$ & $643.9 \mathrm{~m}$ \\
\hline & & $2185.0^{\prime}$ & $14.8^{\prime}$ & 2169.2' & & $72.2^{\prime}$ & 2112.8 \\
\hline \multirow[t]{2}{*}{ Suleiman 1} & 26.04 .05 & $671.5 \mathrm{~m}$ & $5.0 \mathrm{~m}$ & $666.5 \mathrm{~m}$ & 1.3 & $22.0 \mathrm{~m}$ & $649.5 \mathrm{~m}$ \\
\hline & & 2203.5 & $16.4^{\prime}$ & $2186.6^{\prime}$ & & $72.2^{\prime}$ & 2130.8 \\
\hline \multirow[t]{2}{*}{ Suleiman 2} & 28.04 .05 & $671.6 \mathrm{~m}$ & $5.0 \mathrm{~m}$ & $666.0 \mathrm{~m}$ & 1.2 & $25.0 \mathrm{~m}$ & $646.6 \mathrm{~m}$ \\
\hline & & 2203.5 & $16.4^{\prime}$ & 2187.1' & & 82.0 ' & 2121.5' \\
\hline \multirow{2}{*}{ Main Gate } & 4.07 .05 & $668.6 \mathrm{~m}$ & $7.5 \mathrm{~m}$ & $661.3 \mathrm{~m}$ & 1.4 & $15.0 \mathrm{~m}$ & $653.6 \mathrm{~m}$ \\
\hline & & 2193.5, & $24.6^{\prime}$ & 2168.9' & & $49.2^{\prime}$ & 2144.3' \\
\hline Youth & 20.11 .02 & $666.9 \mathrm{~m}$ & $5.4 \mathrm{~m}$ & $661.5 \mathrm{~m}$ & $?$ & $5.6 \mathrm{~m}$ & $661.3 \mathrm{~m}$ \\
\hline Corps & & 2188.0' & $17.6^{\circ}$ & 2170.4' & & 18.3' & 2169.7' \\
\hline
\end{tabular}

Table 3: Summary of the Borehole Logs Drilled in the Abu Teaching Area to Supplement Surface Water Supply.

\begin{tabular}{|c|c|c|c|c|c|}
\hline \multirow[t]{2}{*}{ Water well } & \multicolumn{3}{|c|}{ Soft overburden, $\mathrm{m}$ bgl } & \multirow[t]{2}{*}{ Crystalline rock, $\mathrm{m}$ bgl } & \multirow[t]{2}{*}{ Crystalline rock, petrology } \\
\hline & Clay & Sand & Total & & \\
\hline Amina 1 & $0-12$ & $12-25$ & 25 & $25-37.5$ & Migmatite gneiss? \\
\hline Amina 2 & $0-10$ & $10-23$ & 23 & $23-30$ & Migmatite gneiss? \\
\hline Ribadu 1 & $0-8$ & $8-25$ & 25 & $25-40$ & Migmatite gneiss? \\
\hline Ribadu 2 & $0-10$ & $10-20$ & 20 & $20-37$ & Migmatite gneiss? \\
\hline Library & $0-10$ & $10-20$ & 20 & $20-30$ & Migmatite gneiss? \\
\hline Akenzua 1 & $0-15$ & $15-18$ & 18 & $18-27$ & Migmatite gneiss? \\
\hline Akenzua 2 & $0-17$ & $17-22$ & 22 & $22-27$ & Migmatite gneiss? \\
\hline Suleiman 1 & $0-11$ & $11-22$ & 22 & $22-37$ & Migmatite gneiss? \\
\hline Suleiman 2 & $0-9$ & $9-25$ & 25 & $25-36.5$ & Migmatite gneiss? \\
\hline Main Gate & $0-10$ & $10-15$ & 15 & $15-42$ & Granite \\
\hline Youth Corps & $0-5.6$ & - & 5.6 & $5.6-5.7$ & Gneissose granite \\
\hline
\end{tabular}

Drainage basin of the Kubanni River, upstream from the spillway, is $54 \mathrm{~km}^{2}$. Depth of mean annual rainfall is $1,100 \mathrm{~mm}$. Therefore mean annual volume of rainfall is $59,400,000 \mathrm{~m}^{3}$. This is corresponding to total run-off coefficient of 0.15 . Duration of the dry season is 200 days. Total dynamic water resources (TDWR) of the Kubanni river catchment area at the spillway measured as the volume of total run-off are $8,910,000 \mathrm{~m}^{3} / \mathrm{a}$ or $24,410 \mathrm{~m}^{3} / \mathrm{d}$ see table 4 . The active storage of the impounding reservoir, is $750,000 \mathrm{~m}^{3}$, making safe yield to be $3,571 \mathrm{~m}^{3} / \mathrm{d}$. Installed capacity of the waterworks is $4,500 \mathrm{~m}^{3} / \mathrm{d}$. Loss in distribution is $10 \%$, the water available or the utilizable dynamic water resources, is $3,571 \mathrm{~m}^{3} / \mathrm{d}-357 \mathrm{~m}^{3} / \mathrm{d}=3,214 \mathrm{~m}^{3} / \mathrm{d}$. There are two interconnected aquifers in $\mathrm{ABU}$ Campus. The fractured crystalline aquifer and the soft overburden aquifer both aquifers have one water table as shown in figures 3 and 4 .

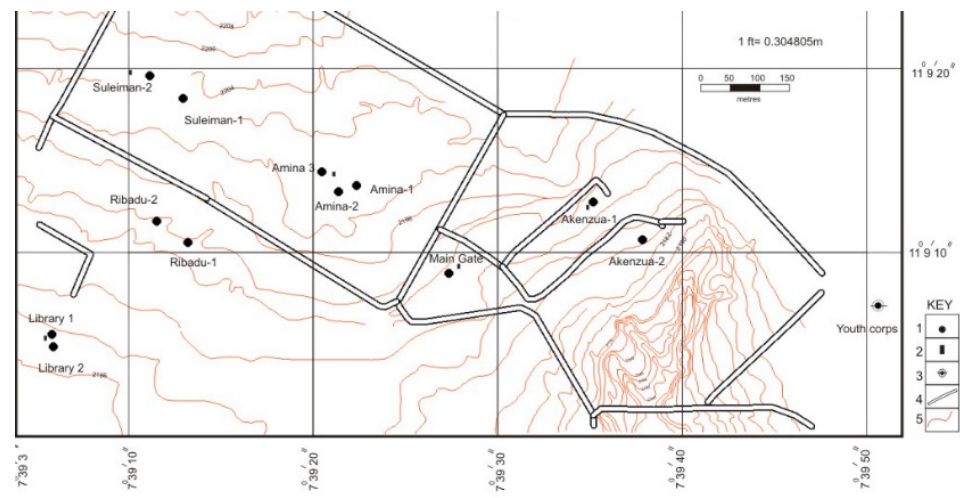

Figure 2 LOCATION AND NAMES OF WATER WELLS, DRILLED AND SUNK IN 2002, 2005 AND 2006 TO SUPPLEMENT SURFACE WATER

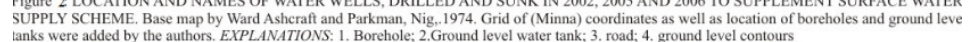

Table 1 seems to suggest that there is no difference in depth to water table between the dry and wet season. The aquifers are recharged not only by rain but also by effluents from the septic tanks in Samaru and the Campus. It would mean that the groundwater in both aquifers is perhaps biologically and chemically polluted and not suitable for drinking. The soft overburden aquifer consists of the alluvial sand. Its thickness and extent is shown in figure 5. This aquifer has been named by the writer as "older alluvial 
aquifer", to distinguish it from the "recent alluvial aquifer" in the Kubanni River Valley, outside of the study area. It is possible that in the eastern and southern part of the map shown in figure 5 the older alluvial aquifer is absent. Its area, measured on figure 5 is $494,109 \mathrm{~m}^{2}$ (49 ha), its average weighed thickness derived from the base map is $8.6 \mathrm{~m}$, effective porosity is 0.10 and the total static water resources therefore, is $425,754 \mathrm{~m}^{3}$. Total dynamic water resources of the older alluvial aquifer is $27,176 \mathrm{~m}^{3} / \mathrm{a}$ or $74 \mathrm{~m}^{3} / \mathrm{d}$, calculated as rainfall recharge, at the depth of rainfall of $1,100 \mathrm{~mm} / \mathrm{a}$, infiltration coefficient of 0.05 .

\begin{tabular}{|c|c|c|c|c|}
\hline Dynamic Water Resources & $\begin{array}{c}\text { Total Water Resources } \\
\mathrm{m}^{3} / \mathrm{a}\end{array}$ & $\begin{array}{l}\text { Utilizable Water Resources } \\
\mathrm{m}^{3} / \mathrm{d}\end{array}$ & $\mathrm{m}^{3} / \mathrm{a}$ & $\mathrm{m}^{3} / \mathrm{d}$ \\
\hline Surface Dynamic Water Resources & $8,910,00024,410$ & $1,173,040 \quad 3,214$ & & \\
\hline Groundwater Dynamic Resources & 27,176 & 13,588 & & \\
\hline TDWR & $8,937,176 \quad 24,484$ & $1,186,628$ & 3,251 & \\
\hline
\end{tabular}

At this depth of rainfall, infiltration coefficient under normal land use conditions is 0.15 . The older alluvial aquifer has been divided into three members on the basis of granulation. The area covered by the older alluvial aquifer and its thickness is shown in figure 5, while the extent and thicknesses of its three members are shown in figures 6,7 and 8. The upper and lower members are fine sand, while the middle member consists of coarse and sometimes pebbly sand. Thickness and extent of the upper member is shown in figure 6 . It average thickness is $3 \mathrm{~m}$, thickness and extent of the middle member is shown in figure 7. It is also about $3 \mathrm{~m}$ thick, but it is possible that in northwest direction its thickness may exceed 10 meters. Thickness and extent of the lower member is shown in figure 8 , As it is with the upper two members, its thickness is about $2.6 \mathrm{~m}$. Configuration of the top of the fractured crystalline aquifer is shown in figure 9 , while depth to the top of the fresh crystalline rock is shown in figure 10. Vertical configuration of the older alluvial aquifer is shown in the hydrogeological crosssection in figure 11. Little or nothing is known on the other features, like petrology or the hydraulic properties of this aquifer. It has not been proved whether the fresh rock on the ABU campus is fractured, because there was only one pumping test after the borehole was completed in the crystalline rock. Hydrogeological cross-section in figure 11 and hydrogeological correction in figure 12 provides more information on the groundwater occurrence within the Study Area.

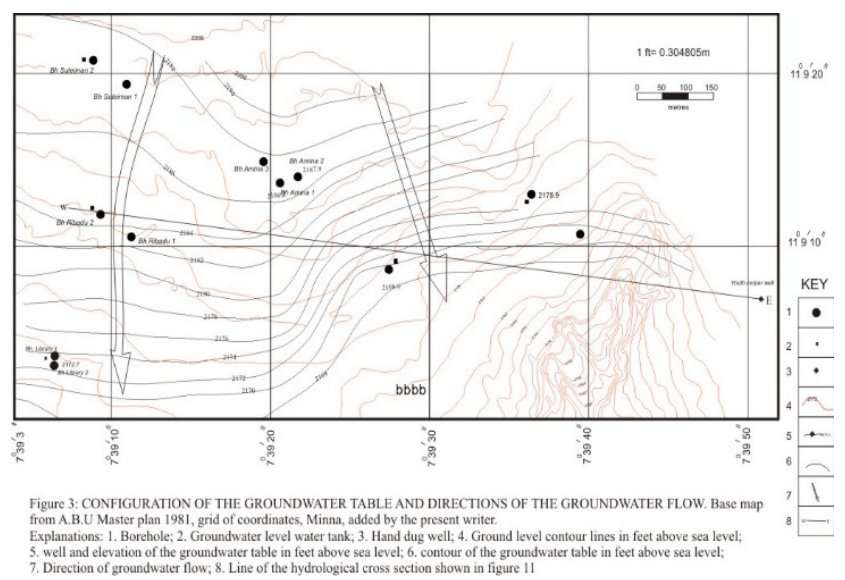

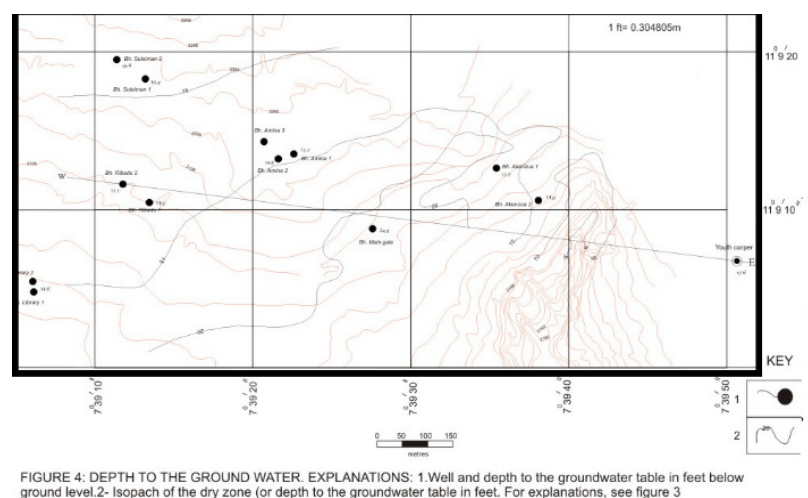



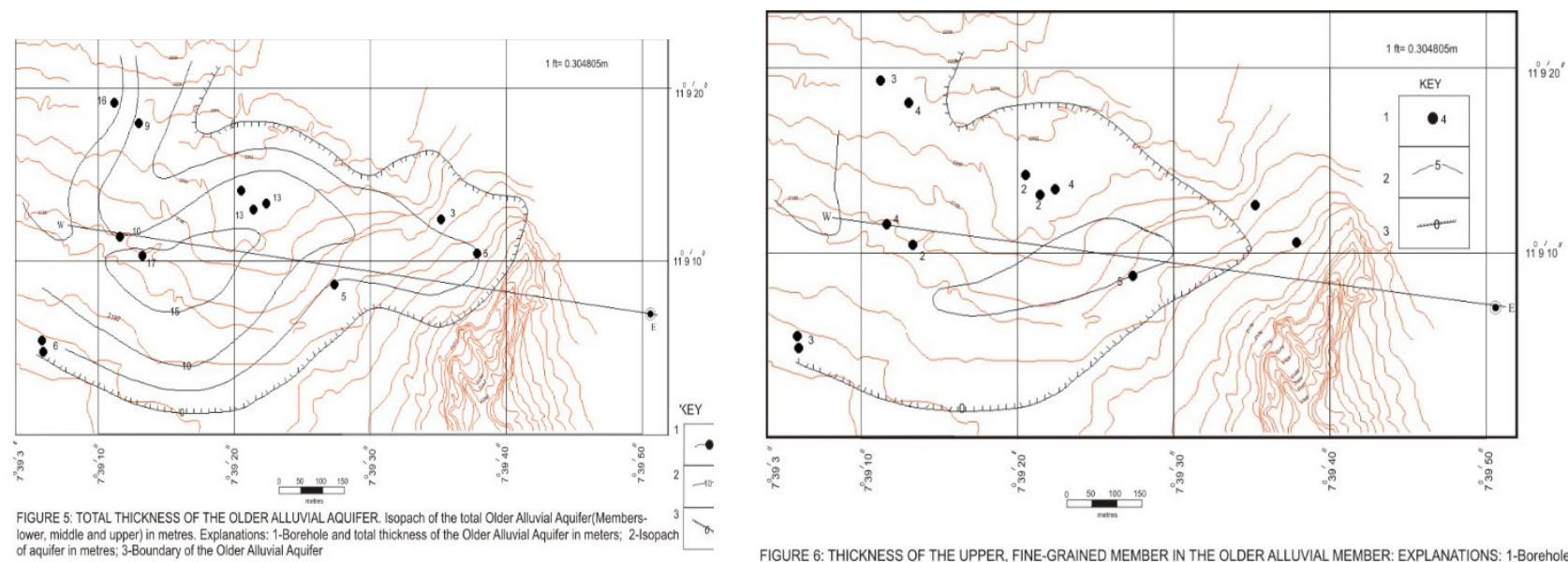
of aquifer in metres; 3-Bundary of the Older Alluvial Aquifer

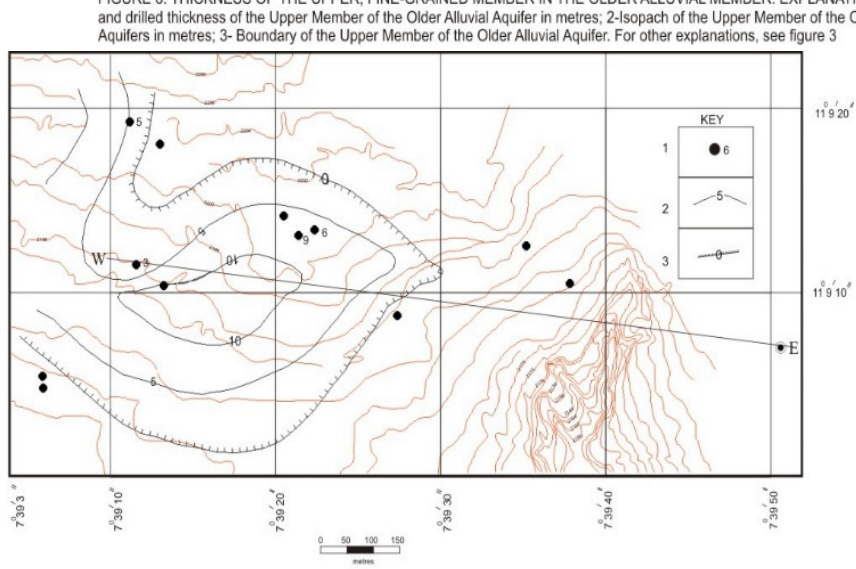

FIGURE\& : THICKNESS OF THE LOWER, FINE-GRAINED MEMBER OF THE OLDER ALLUVIALAQUIFER. Explanations 1-Borehole and drilled thickness of the Lower Member of the Older Aquifer in metres; 2--ssopach of the Lower Member of the
Older Alluvial Aquifer in metres. 3 -Boundary of the Lower Member of the Older Aquifer. See Figure 3 for more explanations.

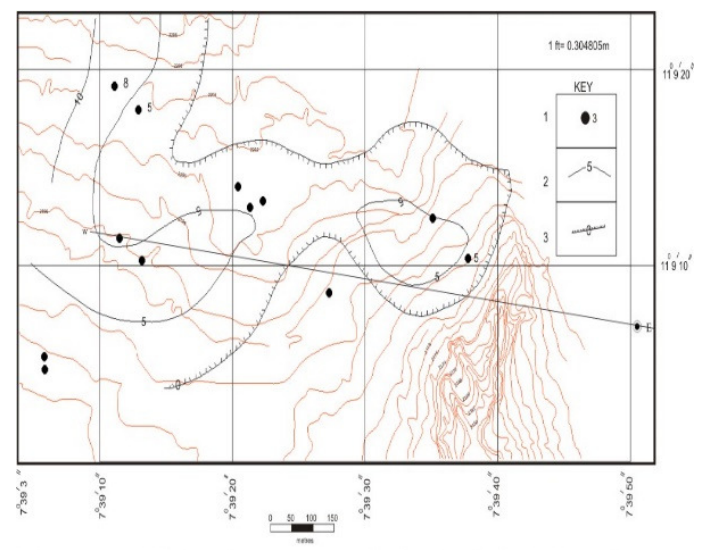

FGURE7: THICKNESS OF THE MIDDLE, COARSE-GRANED MEMBER OF THE OLDER ALLUVIALAQUIFER, Explantioge

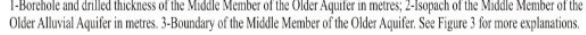



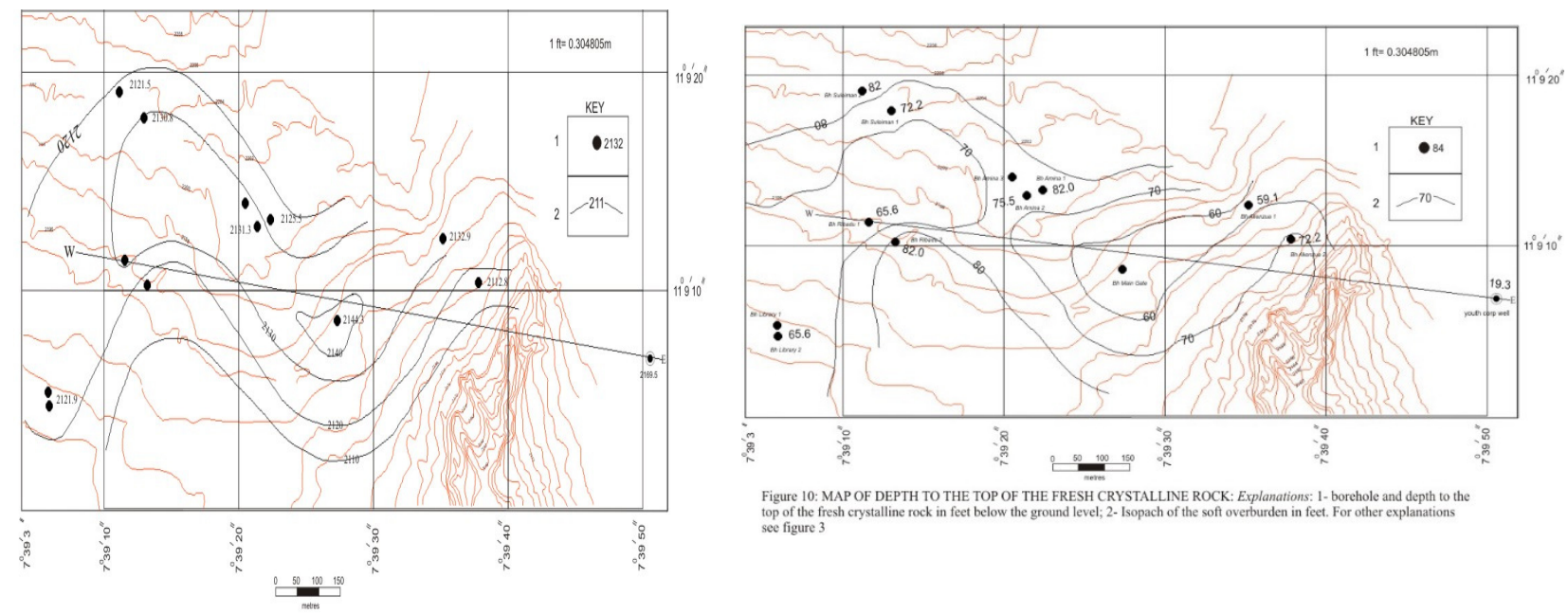

FIGURE 9:CONFIGURATION OF THE TOP OF THE FRESH CRYSTALLINE ROCK. EXPLANATIONS. I-Borehole and elevetion

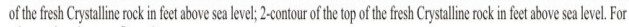
other explanations see figure 3.

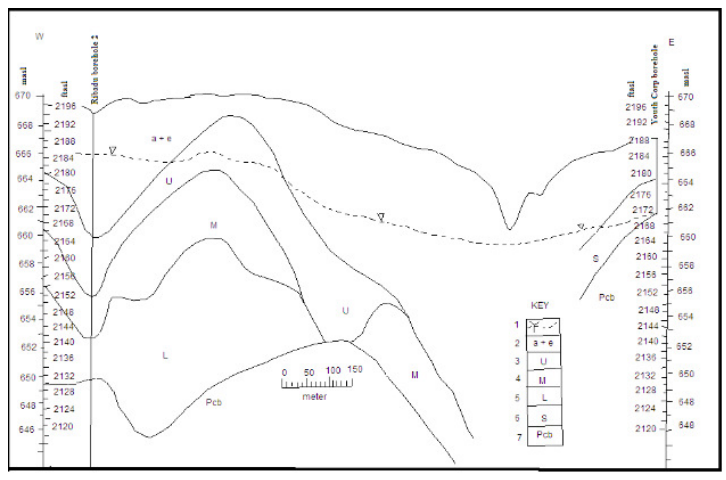

Fig 11. Hydrogeological Cross-Section. For location of the cross-section, see maps in figures 3, 4, 5,6, 7, 8, 9, and 10. Vertical exaggeration x31. Explanations: 1 - Water table, as recorded in table 1 and shown in figures 3 and 4: 2 - Anthropogene and eolian silt; 3 - Upper, fine grained Member in the Older Alluvial Aquifer; 4 - Middle, coarse grained Member in the Older Alluvial Aquifer; 5 - Lower, fine grained Member in the Older Alluvial Aquifer, 6 - Saprolite; 7 Precambrian crystalline rocks, undifferentiated.

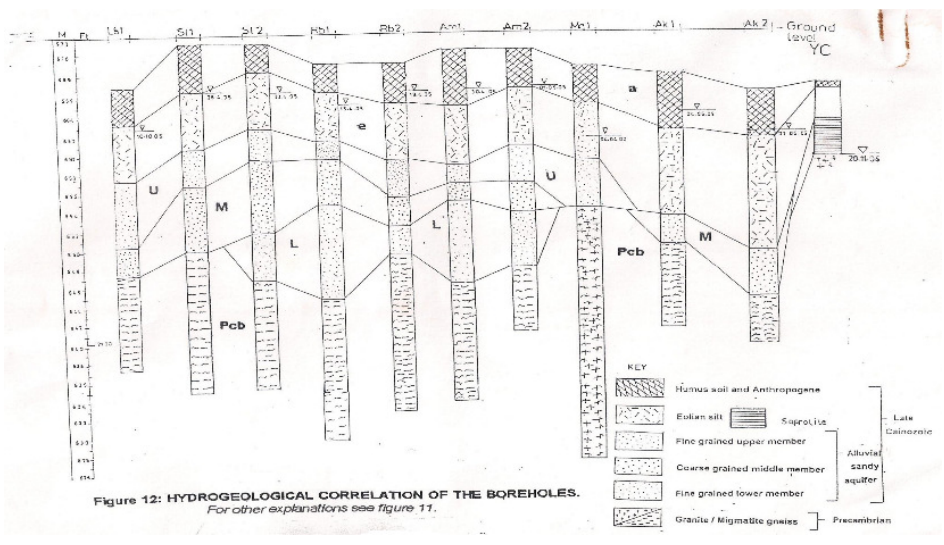

Conclusion : Comparison of the utilizable dynamic water resources at the $\mathrm{ABU}$ main campus with the Water Consumption at the Campus shows that there is slight surplus of the water resources over the water consumption. It means that there is no scarcity of water at the source in the Campus as shown in figure 5. 


\begin{tabular}{lcll}
\hline TABLE 5: Water Budget for Main Campus of the Ahmadu Bello University. & \\
\hline Utilizable Dynamic Water & Water Consumption in Year 2005 & Water Budget in & \\
Resources, $\mathrm{m}^{3} / \mathrm{d}$ & $\mathrm{m}^{3} / \mathrm{d}$ & Year $2005 \mathrm{~m}^{3} / \mathrm{d}$ \\
3,251 & 3,101 & \\
& Water Consumption in Year 2015 & Water Budget in & \\
Utilizable Dynamic Water & $\mathrm{m}^{3} / \mathrm{d}$ & Year $2015 \mathrm{~m}^{3} / \mathrm{d}$ \\
Resources, $\mathrm{m}^{3} / \mathrm{d}$ & 3,125 & & +126 \\
\hline 3,251 & & & \\
\hline
\end{tabular}

It has been proved that the surface water, $24,410 \mathrm{~m}^{3} / \mathrm{d}$ of run-off from the catchment area which is $3,214 \mathrm{~m}^{3} / \mathrm{d}$ of raw water is sufficient to meet the water demand from the Campus which is $3,101 \mathrm{~m}^{3} / \mathrm{d}$ in the year 2005 and $3,125 \mathrm{~m}^{3} / \mathrm{d}$ in year 2015 . The safe yield of the Kubanni Dam will not be reduced by siltation. It has been calculated that the available groundwater in the Campus is negligible ( $\left.37 \mathrm{~m}^{3} / \mathrm{d}\right)$ and not enough to be a supplement to surface water. The volume, $425,754 \mathrm{~m}^{3}$ of the groundwater, accumulated during several years in the aquifer, is not enough to meet half of the present annual water consumption of $1,131,865 \mathrm{~m}^{3}$. It was proved that the groundwater is not an alternative to the surface water. Overhead tanks and valves on the mains, should be reactivated. Total surface water resources are $24,410 \mathrm{~m}^{3} / \mathrm{d}$ while utilizable surface water resources are $3,214 \mathrm{~m}^{3} / \mathrm{d}$, which is still more than the water consumption. Utilizable groundwater resources are negligible. Based on the geology of the study area, hydrogeological correlation, cross section of the boreholes, configuration of the groundwater table flow direction, depth to the top of the fresh crystalline rock proof there was no need for the boreholes to be drill in the area because the groundwater empty into the surface water body (the Kubanni Dam). This study has shown that there is enough surface water to meet water demand from the Campus now and in the future. There was no need to tap groundwater as supplement to the surface water considering the environmental impact to the depth of groundwater, total thickness of the upper fine grained, middle coarse grained, and lower fine grained member of the older alluvial aquifer that is overlaying the crystalline rock.

\section{REFERENCES}

Agema, B., (2007); Sustainability of non-piped water supplies to Samaru Town, Zaria. Geol 411 Seminar Paper presented on 24.02.2007 to the Department of Geology, ABU Zaria.
Committee on Water Resources and Supply (CWRS) (2004); Unpublished Report for the Vice Chancellor, Ahmadu Bello University Zaria.

Garba, M.L. (2000); Lead (Pb) Concentration in the Water of Kubanni Dam, Zaria Unpublished master's thesis, submitted to the Department of Geology Ahmadu Bello University, Zaria.

National Water Resources Institute (2002); Report on a borehole drilled at Main Gate ABUMain Campus, Zaria for the Estate Department, Ahmadu Bello University Zaria. Unpublished as done report in files of the Groundwater Research Department, National Water Resources Institute, Kaduna. 